\title{
Fabrication of Electrode Groove on Silicon Solar Cell using High-Pressure Surface Discharge
}

\author{
Toshiyuki Hamada Student Member (University of Miyazaki, hamada@epl.opt.miyazaki-u.ac.jp) \\ Shunichi Arakawa Non-member (University of Miyazaki, arakawa@epl.opt.miyazaki-u.ac.jp) \\ Masahisa Otsubo Member (University of Miyazaki, otsubo@cc.miyazaki-u.ac.jp) \\ Tatsuya Sakoda Member (University of Miyazaki, sakoda@cc.miyazaki-u.ac.jp)
}

Keywords : silicon nitride film, surface discharge, single crystalline silicon solar cell, back electrode length, electrode groove, front contact

\section{Introduction}

On typical surfaces of solar cells, antireflection films for a further reduction in light reflection intensity from the solar cell surfaces with randomly distributed pyramid-like structures are formed on $\mathrm{n}^{+}$layers. For the fabrication of front contacts on solar cells, it is desired that the parts of an antireflection film where the electrodes are formed are removed, because the film functions as barrier in obtaining electric power. Therefore, we proposed a low-cost plasma process technique to fabricate narrower front electrode grooves on a single crystalline silicon solar cell, in which the surface discharge operated at high-pressure etched the silicon nitride film of $150 \mathrm{~nm}$ thickness on a silicon layer.

\section{Experiments}

Figure 1 shows discharge images taken from the vertical direction with respect to a side face of a convex part of a dielectric electrode at the discharge voltage $\left(V_{d}\right)=4.5 \mathrm{kV}$ and back electrode lengths $(l)$ of $2 \mathrm{~mm}$ and $4 \mathrm{~mm}$. Ar and $\mathrm{CF}_{4}$ flow rates were 700 $\mathrm{sccm}$ and $300 \mathrm{sccm}$, respectively. The surface discharge initiated at the triple junction line where the quartz glass layer, gas space and the cut substrate surface, and the entire side faces of the convex part were covered with innumerable surface streamers. From Figure 1, the length of the surface streamers correspond to the length of the back electrode.

Figure 2 shows images of treated substrates at pressure in chamber $(p)$ of $101 \mathrm{kPa}$ and $152 \mathrm{kPa}$. In this case, $V_{d}$, Ar flow rate, $\mathrm{CF}_{4}$ flow rate, and $t_{e}$ were $4.8 \mathrm{kV}, 700 \mathrm{sccm}, 300 \mathrm{sccm}$, and $10 \mathrm{~s}$, respectively. The uniform grooves are obtained by etching of silicon nitride, which is due to a large number of surface streamers formed on the lateral faces of dielectric electrodes. Additionally, the groove width for $p=152 \mathrm{kPa}$ is obviously narrower than that

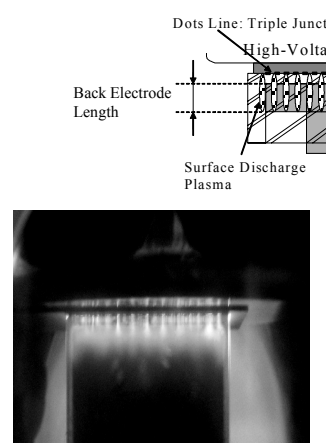

(b) $l=2 \mathrm{~mm}$

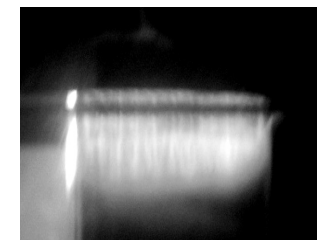

(c) $l=4 \mathrm{~mm}$
Fig. 1. Discharge images at $V_{d}=4.5 \mathrm{kV}$ and $p=152 \mathrm{kPa}$ for the cases of (c) $l=2$ and (d) $4 \mathrm{~mm}$

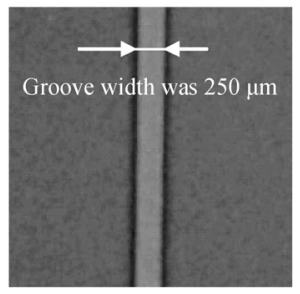

(a) $p=101 \mathrm{kPa}$

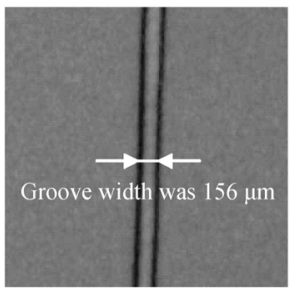

(b) $p=152 \mathrm{kPa}$
Fig. 2. Images of treated substrates at $V_{d}=4.8 \mathrm{kV}$ and $t_{e}=10 \mathrm{~s}$ for the cases of (a) $p=101 \mathrm{kPa}$ and (b) $p=152 \mathrm{kPa}$

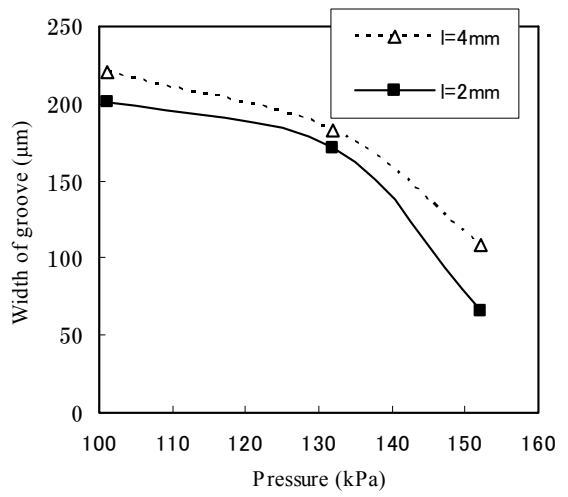

Fig. 3. Pressure dependence on groove width at $V_{d}=5.0 \mathrm{kV}$ for the cases of (a) $l=2 \mathrm{~mm}$ and (b) $l=4 \mathrm{~mm}$

for $p=101 \mathrm{kPa}$.

Figure 3 shows pressure $(p)$ dependence on the groove width at $V_{d}=5 \mathrm{kV}$ for the cases of (a) $l=2$ and (b) $l=4 \mathrm{~mm}$. The groove widths for $p=152 \mathrm{kPa}$ are narrower than these for $p=101 \mathrm{kPa}$. From Fig. 3, it was found that the height of the back electrode and $p$ played essential roles in reduction of the width of the electrode groove. In other words, the shorter the height of the back electrode and higher $p$ at each $V_{d}$, the narrower the width of the electrode groove becomes.

\section{Summary}

In order to investigate an optimum surface discharge condition for preparing narrow electrode grooves, fabrications were carried out for various $p$ and $l$. The width of the groove became narrow with the increase of the $p$, and the a short $l$ was effective to fabricate the narrow electrode groove. 


\title{
高気圧沿面放電による太陽電池用電極溝の作製

\author{
学生員 濱田 俊之* ${ }^{*}$ 非会員 荒川 純一 ** \\ 正 員 大坪 昌久*** 正員 迫田 達也***
}

\author{
Fabrication of Electrode Groove on Silicon Solar Cell using High-Pressure Surface Discharge \\ Toshiyuki Hamada*, Student Member, Shunichi Arakawa**, Non-member, Masahisa Otsubo***, Member, \\ Tatsuya Sakoda***, Member
}

\begin{abstract}
We proposed a low-cost plasma process technique to fabricate narrower front electrode grooves on a single crystalline silicon solar cell, in which the surface discharge operated at high-pressure etched the silicon nitride film of $150 \mathrm{~nm}$ thickness on a silicon layer. The results showed that the surface discharge could effectively etch the silicon nitride film in a short time and that a high etching rate more than $3000 \mathrm{~nm} / \mathrm{min}$ was obtained. The narrow and uniform grooves with the width of less than $70 \mu \mathrm{m}$ were obtained when the pressure in a chamber, the back electrode length and the etching time were $152 \mathrm{kPa}, 2 \mathrm{~mm}$ and $10 \mathrm{~s}$, respectively. The narrower electrode groove could be obtained when the back electrode length was short and the pressure was high.
\end{abstract}

キーワード : 窒化シリコン膜, 沿面放電, 単結晶シリコン太陽電池, 背後電極長, 電極溝, 受光面電極

Keywords : silicon nitride film, surface discharge, single crystalline silicon solar cell, back electrode length, electrode groove, front contact

\section{1. はじめに}

結晶シリコン系太陽電池に受光面電極を形成する際，電 極パターンの形状に合わせて反射防止膜を除去した電極溝 を作製することが太陽電池の高効率化には有効であり，太 陽電池回路内の直列抵抗を低減化できる。また，作製した 電極溝表面の $\mathrm{n}$ 型層に高濃度のリン拡散，または電極ぺー スト自体にリンやボロン等を高濃度に含有させて電極を形 成することで, $\mathrm{n}^{++}$拡散層を設けた選択エミッタ構造にする ことができる。この選択エミッタ構造によって, 受光面電 極近傍でのキャリア再結合を抑制することが可能となり， 太陽電池の高性能化を図ることができる(1)。

ところで，現在の主な電極作製法としては，スクリーン 印刷法や鍍金法等が挙げられる。スクリーン印刷法は非常 に生産性に富み，自動化も容易であり，かつ材料の使用収

\footnotetext{
* 宮崎大学大学院農学工学総合研究科

干889-2192 宮崎市学園木花台西 1-1

Interdisciplinary Graduate School of Agriculture and Engineering, University of Miyazaki

1-1, GakuenKibanadai-Nishi, Miyazaki 889-2192

** 宮崎大学大学院工学研究科

干889-2192 宮崎市学園木花台西 1-1

Graduate School of Engineering, University of Miyazaki

1-1, GakuenKibanadai-Nishi, Miyazaki 889-2192

*** 宮崎大学工学部電気電子工学科

† 889-2192 宮崎市学園木花台西 1-1

Department of Electrical and Electronic Engineering, University of Miyazaki

1-1, GakuenKibanadai-Nishi, Miyazaki 889-2192
}

率にも優れるという特徵があるが, 電極パターンの微細度 がスクリーン印刷の精度に制限されるため, 現在の量産可 能な電極パターン幅は $100 \mu \mathrm{m}$ 程度である。鍍金法は印刷法 に比べてコストは高くなるものの, より微細な電極を形成 することが可能であり，電極の影による損失（シャドーロ ス）が低減でき, 高性能な太陽電池の作製が可能である(2)。 いずれの電極形成法を用いる場合においても，選択エミッ 夕構造を導入する前処理として電極パターンに合わせた電 極溝を作製することは太陽電池の曲線因子 (F.F. : Fill factor) を改善するのに有効である。また, 電極溝は数 $\mu \mathrm{m}$-数十 $\mu \mathrm{m}$ の深さで掘削することで電極と半導体との接触面積を増加 させるとともに, シャドーロスの少ない埋め込み型電極と するのも有効である ${ }^{(3)}$ 。このような電極溝作製手法として は, レーザアブレーションによる手法, ダイシング装置な ぞによる機械的加工手法, ホトリソグラフィーとエッチン グを用いる手法がある。しかし，レーザによる手法は処理 面が粗く, 受光面電極の交差する領域での 2 度掘りにより, 十分なオーム接触を得られない問題がある。ダイシング装 置の場合は, ダイヤモンドブレードによる基板表面へのダ メージが大きく，これを除去するために電極溝内を酸性ま たはアルカリ溶液によるエッチング工程を要する(4)。ホトリ ソグラフィーとエッチングを併用する場合は，レジスト材 料の塗布, 露光, エッチング, レジスト剥離という工程が あり，プロセスが非常に複雑となる(5)。 
そこで我々は，シリコン太陽電池表面の電極溝作製に沿 面放電プラズマを適用することを提案した ${ }^{(6)}$ 。本手法におい ては，直角の角を持つガラス誘電体により，金属電極の一 方を被覆することで，ガラス誘電体側面に局所化した沿面 放電プラズマを一様に生成することに成功した。なお，こ こでは太陽電池の受光面を広く確保するため, 幅の細い電 極溝を低コスト且つ，高速で作製することを目的としてい る。著者等は，これまでに $\mathrm{Ar}, \mathrm{CF}_{4}, \mathrm{O}_{2}$ 混合ガスを用いて大 気圧下で沿面放電プラズマを生成し, 太陽電池用単結晶シ リコン基板表面に反射防止膜として形成された窒化シリコ ン $\left(\mathrm{Si}_{3} \mathrm{~N}_{4}\right)$ 膜を選択的にエッチングした電極溝をマスクレス で作製可能であることを報告した ${ }^{(6)}$ 。なお，前述したマスク レスとは，ガラス誘電体側面のみで発生する沿面放電プラ ズマで線状にエッチングを行うため，レジストマスク等を 用いる必要がないことを意味する。作製した電極溝の幅は 放電維持電圧 $\left(V_{d}\right)$, 処理時間 $\left(t_{e}\right)$, ガス流量に依存し, 溝幅約 $150 \mu \mathrm{m}$ の電極溝の作製に成功している(7)(8)。しかし, 受光面 電極であるフィンガー電極幅は約 $100 \mu \mathrm{m}$ 以下であり，電極 溝の更なる細線化が望まれている。本研究では, 新しく立 方体型のガラス誘電体電極を作製し，これを用いて大気圧 以上の高気圧下で沿面放電プラズマを生成し，より細い幅 の電極溝の作製を試みた。なお， $\mathrm{CF}_{4}$ 混合比を調整すること により選択的なエッチングを行うことも可能(6)であるが，こ こでは細い電極溝を作製することに着目し，エッチングが Si に及ぶものも含めた。

\section{2. 実験方法}

電極溝作製装置の概略を図 1 に示す。誘電体には $30 \times 30 \times 30 \mathrm{~mm}$ (公差 $0.1 \mathrm{~mm}, \mathrm{c}=0.1 \mathrm{~mm}$ ), 厚夕 $1 \mathrm{~mm}$ (公差 $0.1 \mathrm{~mm})$ の立方体型構造の石英ガラスを用いた。沿面放電 が発生するガラス誘電体側面の内側には, 沿面放電を生成 させるための背後電極として働く銅薄膜を貼り付けた。な お，銅薄膜は四面ある誘電体ガラス側面のうち，沿面放電 を発生させる 2 面のみ背後電極として貼り付けている。こ の銅薄膜は直径 $10 \mathrm{~mm}$ の支柱付きの SUS 製下部電極と接触 させた。また，ガラス誘電体と銅薄膜との接触部における 放電の発生を抑制するため，ガラス電極内部はシール材で 絶縁した。単結晶シリコン基板（厚み $0.27 \mathrm{~mm}$ ，オリジナル サイズ $125 \times 125 \mathrm{~mm})$ は, $40 \times 25 \mathrm{~mm}$ の小片サイズに切り出 して直径 $70 \mathrm{~mm}$ の SUS 製上部電極と石英ガラス電極の上面 との間に挿入した。因みに, 本研究で取り扱う単結晶シリ コン基板（B. P. SOLAR 製，抵抗率 2-4 $\Omega \mathrm{cm}$ ）は表面に膜厚 約 $150 \mathrm{~nm}$ の $\mathrm{SiN}$ 膜（屈折率約 2.4）が低気圧プラズマ化学 気相成長（LP-CVD）法で形成されている。エッチングガス は $\mathrm{Ar}, \mathrm{CF}_{4}$ 混合ガスをマスフローコントローラにて制御し, それぞれ $700 \mathrm{sccm} ， 300 \mathrm{sccm}$ を沿面放電領域に供給した。 電圧源には $30 \mathrm{kHz}$ の擬似正弦波（パルス幅約 $10 \mu \mathrm{s}$ ) を出力 可能なインバータ電源を用いた。放電維持電圧 $\left(V_{d}\right)$, 及び電 流值は高電圧プローブ，ロゴスキーによって観測した。背 後電極長 $(l)$ は $2 \mathrm{~mm}, 4 \mathrm{~mm}$ とし, 放電管内圧力 $(p)$ は $101 \mathrm{kPa}$,

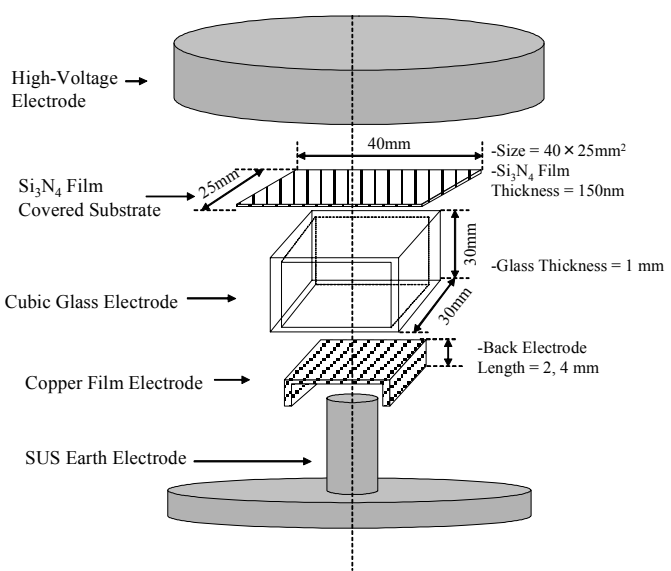

(a) Electrode system

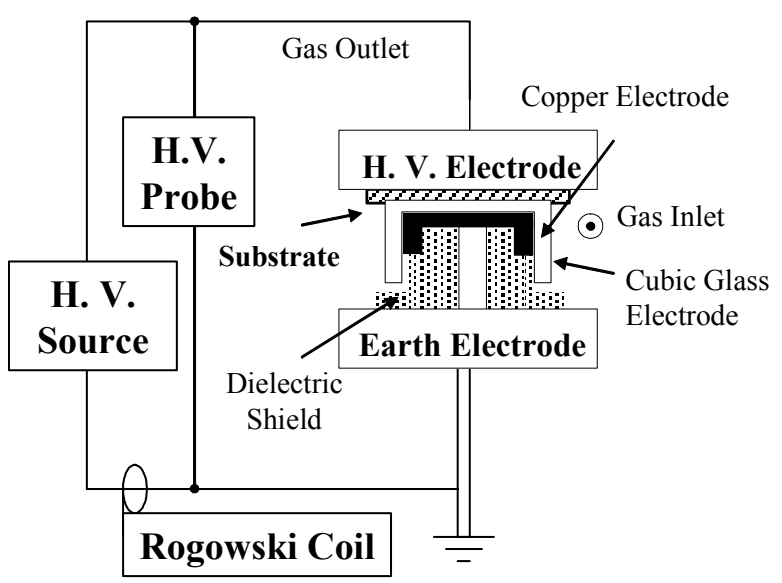

(b) Cross section of etching system

図 1 エッチングシステムの概容

Fig. 1. Schematic diagram of etching system.

$132 \mathrm{kPa}, 152 \mathrm{kPa}$ として沿面放電を生成し, 単結晶シリコン 基板表面のエッチング処理を行った。作製した電極溝の幅 は倍率 50 倍で観測可能なマイクロスコープ (SCALAR 製), 及び同スコープの計測専用ソフト (USB Digital Scale) で溝 幅を計測し, エッチング状況については集束イオンビーム (FIB: Focused Ion Beam) 加工装置により, エッチング領域の 断面加工を行い, 走査イオン顕微鏡 (SIM: Scanning Ion Microscope) を用いて窒化シリコンのエッチング状況を観 測した。

\section{3. 実験結果}

$\langle 3 \cdot 1\rangle$ 放電電圧·電流波形＼cjkstart図 2 に背後電極長 $(l): 2,4$ $\mathrm{mm}$, 放電管内圧力 $(p): 152 \mathrm{kPa}$, 駆動周波数: $30 \mathrm{kHz}$, 放電維 持電圧 $\left(V_{d}\right): 5.0 \mathrm{kV}$ における放電電圧・電流波形を示す。放 電電圧は立ち上がり半值幅約 $6 \mu \mathrm{s}$ の比較的急峻な波形であ る。放電電流は誘電体材料の変位電流成分に沿面放電によ るパルス時間数 ns のパルス成分が重畳している。

$\langle 3 \cdot 2\rangle$ 放電原理と放電写真 放電管内圧力 $(p)=152$ $\mathrm{kPa}, V_{d}=4.5 \mathrm{kV}$, 背後電極長 $(l)$ がそれぞれ $2 \mathrm{~mm}, 4 \mathrm{~mm}$ に おける沿面放電の写真を図 3 に示す。なお, 図 3(a)の放電写 真は沿面放電プラズマ発生領域を斜めから撮影した写真で 


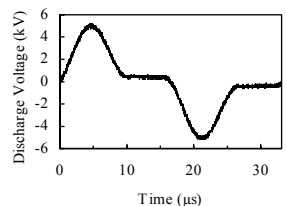

(a) $\mathrm{V}$-t for $l=2 \mathrm{~mm}, p=101 \mathrm{kPa}$

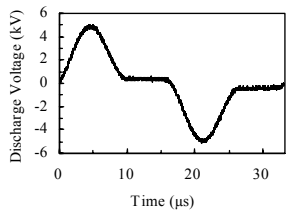

(c) V-t for $l=2 \mathrm{~mm}, p=152 \mathrm{kPa}$

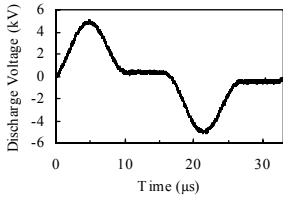

(e) V-t for $l=4 \mathrm{~mm}, p=101 \mathrm{kPa}$

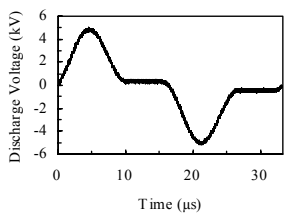

(g) V-t for $l=4 \mathrm{~mm}, p=152 \mathrm{kPa}$

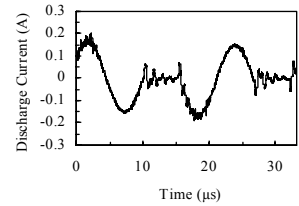

(b) I-t for $l=2 \mathrm{~mm}, p=101 \mathrm{kPa}$

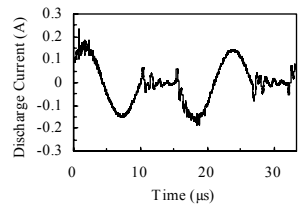

(d) I-t for $l=2 \mathrm{~mm}, p=152 \mathrm{kPa}$

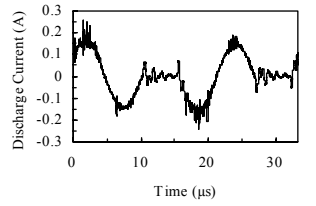

(f) I-t for $l=4 \mathrm{~mm}, p=101 \mathrm{kPa}$

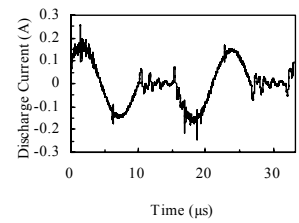

(h) I-t for $l=4 \mathrm{~mm}, p=152 \mathrm{kPa}$

図 2 放電電圧・電流波形

Fig. 2. Waveforms of discharge voltage and discharge current.

ある。ならびに，図 3(b), (c)は沿面放電プラズマ領域を正面 から撮影した放電写真である。沿面放電は図 3(a)における点 線部のような上部電極（シリコン基板下面），ガス空間，ガ ラス誘電体との 3 重点におけるパッシェンの極小点を満た 寸位置より開始される。また， $V_{d}$ の増加に伴い，沿面放電 はガラス誘電体側面を伸展する ${ }^{(7)}$ 。なお, 沿面放電は沿面ス トリーマと呼ばれる非常に電離の盛んな先端の電子雪崩領 域とその後方にあるプラズマ状態の幹から構成される。図 3 から分かるように，沿面ストリーマの長さは背後電極であ る銅薄膜が存在する位置まで伸展することが明らかとなっ た。なお，ストリーマの平均直径は約 $200 \mu \mathrm{m}$ 程度で, 最も 広い領域で約 $250 \mu \mathrm{m}$ であった ${ }^{(7)(8)}$ 。

〈3.3〉 電極溝幅の制御 圧力 $(p)=101,152 \mathrm{kPa}, V_{d}=$ $4.8 \mathrm{kV}, t_{e}=10 \mathrm{~s}$ でエッチング処理を行った際の基板表面写 真を図 4 に示す。図 3 で示した沿面放電写真から明らかな ように沿面ストリーマはガラス誘電体側面を沿って生成さ れるため, 図 4 に示すような直線状のエッチング痕（電極 溝）が作製される。なお，前述したように沿面放電は背後 電極が存在する領域において生成される。本装置の場合, 背後電極が存在する誘電体ガラスの 2 つの側面で背後電極 の幅約 $28 \mathrm{~mm}$ に亘って沿面放電が生成される。従って，1 回のエッチング処理により 2 本の電極溝が作製される。な

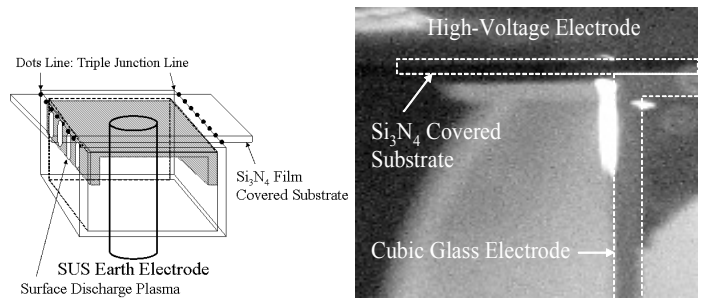

(a) Diagonal direction with $l=2 \mathrm{~mm}$

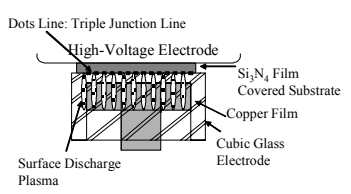

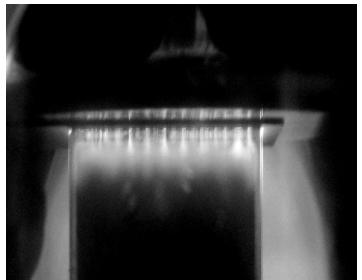

(b) $l=2 \mathrm{~mm}$

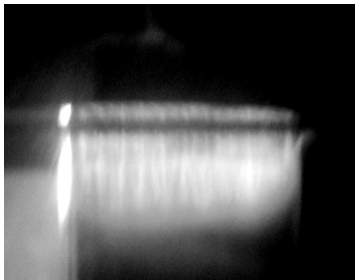

(c) $\quad l=4 \mathrm{~mm}$
図 3 沿面放電写真

Fig. 3. Discharge images at $V_{d}=4.5 \mathrm{kV}$ and $p=152 \mathrm{kPa}$ for the cases of (c) $l=2$ and (d) $4 \mathrm{~mm}$.

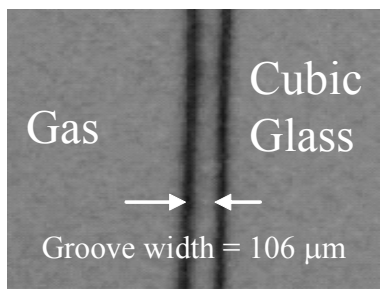

(a) $p=152 \mathrm{kPa}$

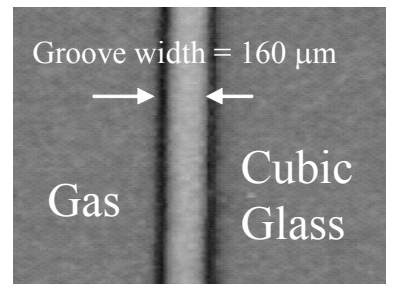

(b) $p=101 \mathrm{kPa}$
図 4 エッチング後のシリコン基板表面写真

Fig. 4. Images of treated substrates at $V_{d}=4.8 \mathrm{kV}$ and $t_{e}=10 \mathrm{~s}$ for the cases of (a) $p=101 \mathrm{kPa}$ and (b) $p=152 \mathrm{kPa}$.

お，図 4 において，ガラス誘電体の上面が接触した領域に は，基板表面に何ら変化は確認されない。すなわち，エッ チングの役割を果たす放電は発生せず, 誘電体ガラスの上 面は物理的なマスク材料としての役割を果たす。一方，エ ッチングはガラス誘電体が密着している領域から外側一約 $200 \mu \mathrm{m}$ 程度まで進行する。これは, 誘電体ガラス側面で生 成される沿面ストリーマの平均直径とほぼ一致しており, 放電は誘電体を離れた領域においては全く発生していない ことを示している。従って, エッチング幅は生成される沿 面ストリーマの直径に大きく依存する。

図 5 に, 背後電極長 $(l)$ が $2 \mathrm{~mm}, 4 \mathrm{~mm}$ における電極溝幅 の圧力 $(p)$ 依存性を示す。このときの放電維持電圧 $\left(V_{d}\right)$ は 5.0 $\mathrm{kV}$ ，エッチング時間 $\left(t_{e}\right)$ は 5 秒である。同図より, $p$ の上昇 に伴い，幅の細い電極溝が作製できることがわかる。また， $l$ が短いと作製される電極溝幅は狭い。従って, 細い幅の電 極溝の作製には, 高い $p$, かつ $l$ を短く設定した状態で沿面 


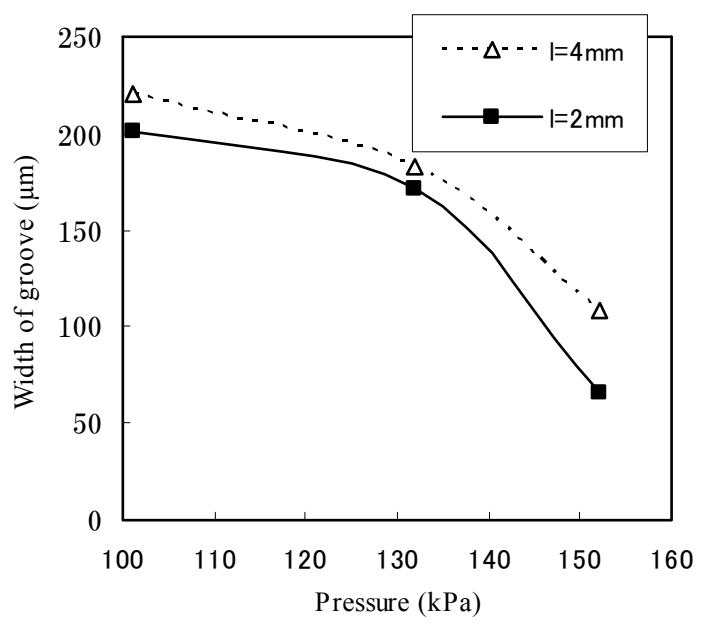

図 5 背後電極長 $l=2 \mathrm{~mm}, 4 \mathrm{~mm}$ における電極溝幅の 管内圧力 $(p)$ 依存性

Fig. 5. Pressure dependence on groove width at $V_{d}=5.0 \mathrm{kV}$ for the cases of (a) $l=2$ and (b) $l=4 \mathrm{~mm}$.

放電を発生させ，エッチングを行うことが有効であるとい える。

次に, 各圧力下における電極溝幅の $V_{d}$ 依存性を図 6 に示 す。本実験では $t_{e}=10 \mathrm{~s}, p=152 \mathrm{kPa}, 101 \mathrm{kPa}$ とし, $l$ は2, $4 \mathrm{~mm}$ において沿面放電を生成した。図 6 の結果より, 溝幅 は $V_{d}$ の上昇に伴い，拡がっていくことが分かる。また，図 5 の結果と同様に $p$ が高く, $l$ が短い方が幅の細い電極溝を 作製可能であることが明らかとなった。なお，本条件にお ける沿面放電の放電開始電圧 $\left(V_{s}\right)$ は $p$ が $101 \mathrm{kPa}$ 時において $3.4 \mathrm{kV}, 152 \mathrm{kPa}$ 時では $4.4 \mathrm{kV}$ であり, $p$ の上昇に伴い $V_{s}$ は 上昇する。また, 得られた最も細い電極溝は $p$ が $152 \mathrm{kPa}$ で $l=4 \mathrm{~mm}$ の場合, $V_{d}=4.0 \mathrm{kV}$ 時において $68 \mu \mathrm{m}$ であった。 $l=$ $2 \mathrm{~mm}$ の場合は, $V_{d}=4.6 \mathrm{kV}$ 印加時において $73 \mu \mathrm{m}$ であった。

各背後電極長 $(l)$ における電極溝幅のエッチング時間 $\left(t_{e}\right)$ 依 存性を図 7 に示す。この時の $p$ 及び $V_{d}$ はそれぞれ $152 \mathrm{kPa}$, $5.0 \mathrm{kV}$ である。図 7 より, 溝幅は $t_{e}$ に比例して拡がる。ま た, 電極溝幅の拡がりは約 $200 \mu \mathrm{m}$ 程度で飽和する傾向にあ る。従って，短時間でエッチング処理することが，細い電 極溝を作製するのに有効であることが明らかとなった。

〈3·4〉 エッチング状況の観察 〈3・3〉節では, 電極 溝の幅に関することのみ言及したが，本節ではエッチング による基板表面の形状と, SiN 膜のエッチングを確認した結 果について述べる。まず，FIB 装置により電極溝の中心領域 及びエッジ領域を加工幅約 $20 \mu \mathrm{m}$ でエッチング面の断面加 工を行った後, SIMによる断面観察を行った。

圧力 $(p)=152 \mathrm{kPa}, V_{d}=4.8 \mathrm{kV}, t_{e}=10 \mathrm{~s}$ でエッチング処理 を行った際の基板断面 SIM 像を図 8 に示す。図中のタング ステンコートは，加工の際に FIB 装置より照射されるガリ ウムイオンの照射からシリコン基板表面を保護するために 加工領域付近に蒸着した。なお，太陽電池用単結晶シリコ ン基板表面には，基板表面の光反射を低減させるためのピ ラミッド状テクスチャ構造 (頂角 70.5 度, 表面粗さ約 $10 \mu \mathrm{m}$ )

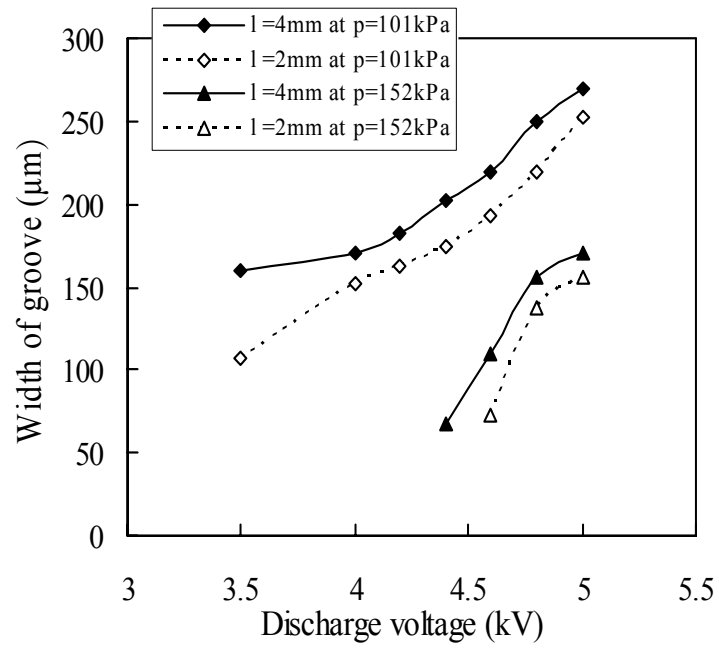

図 6 電極溝幅の放電維持電圧 $\left(V_{d}\right)$ 依存性

Fig. 6. Discharge voltage dependence on groove width for the cases of $p=101 \mathrm{kPa}$ and $152 \mathrm{kPa}$.

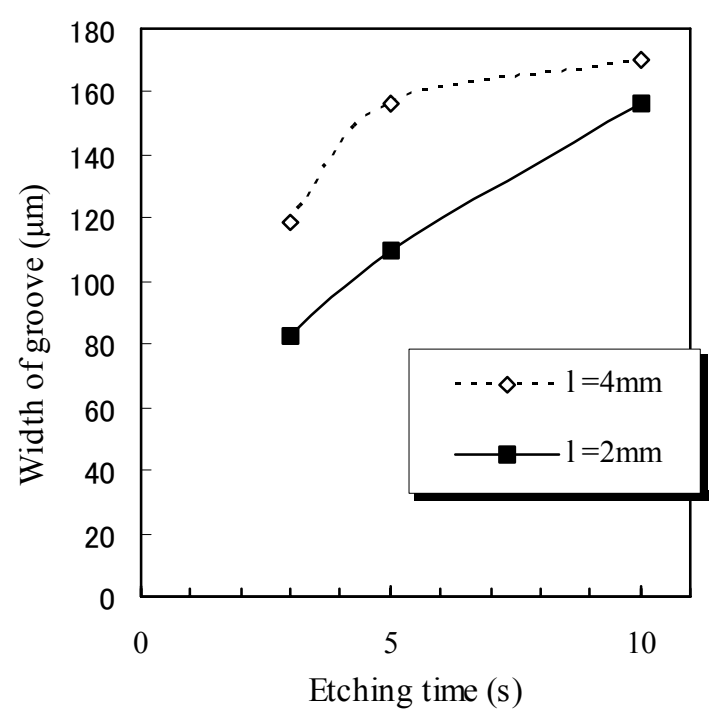

図 7 背後電極長 $l=2 \mathrm{~mm}, 4 \mathrm{~mm}$ における電極溝幅の 処理時間依存性

Fig. 7. Etching time dependence on groove width. $V_{d}$ and $p$ were $5.0 \mathrm{kV}$ and $152 \mathrm{kPa}$, respectively.

が湿式処理により形成されており, そのテクスチャ面上に 膜厚約 $150 \mathrm{~nm}$ の $\mathrm{SiN}$ 膜が形成されている。図 8 より, プラ ズマ未処理領域においては, 反射防止膜である $\mathrm{SiN}$ 膜が確 認できるが，沿面放電によりエッチングされた領域では, $\mathrm{SiN}$ 膜が完全にエッチングされていることがわかる。しか し，電極溝領域の幅方向において，エッジから約 $20 \mu \mathrm{m}$ に わたる領域では, SiN の残膜が確認され, この残膜は電極溝 のエッジに向かうにつれて増加してゆく。

以上のように，本手法においては電極溝の幅方向のみな らず深さ方向にもエッチングは進展する。なお, $p=152 \mathrm{kPa}$, $V_{d}=5.0 \mathrm{kV}$ の場合, $t_{e}=3 \mathrm{~s}$ で図 8 の結果とほぼ同様な結果 が得られた。従って, 膜厚 $150 \mathrm{~nm} の \mathrm{SiN}$ 膜を $3 \mathrm{~s}$ でエッチ 


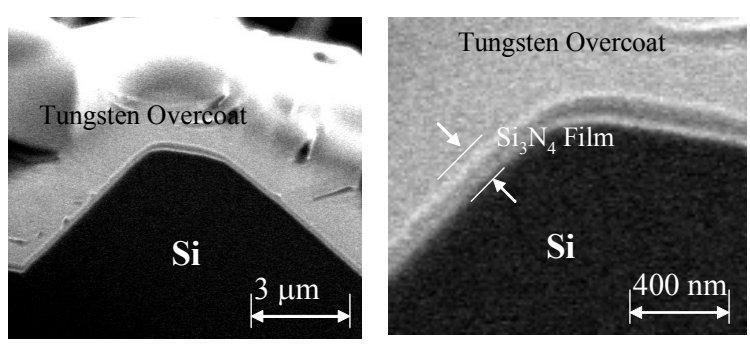

(a) No treatment

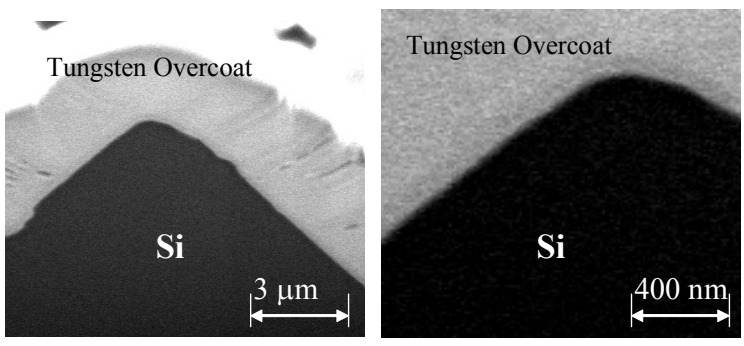

(b) Plasma etched area
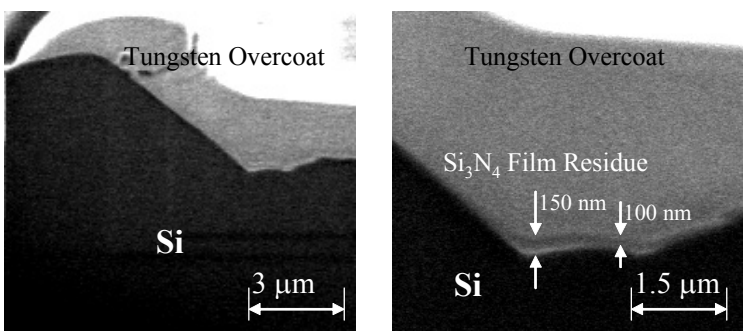

(c) Groove edge area

図 8 電極溝断面 SIM 像

Fig. 8. SIM images of (a) No treatment, (b) Plasma etched area, and (c) Groove edge area.

ングが可能であることから，1 分間当たりのエッチングレー トに換算すると，約 $3000 \mathrm{~nm} / \mathrm{min}$ となる。

\section{4. 考 察}

実験結果より, より細い電極溝の作製には, $p$ を高く保ち, $l$ を短く設定することが重要であることが明らかとなった。 $p$ が高くなると, 放電領域において粒子間衝突が非常に活発 となるため, 電子との衝突距離である平均自由行程が短く なる。従って，生成される沿面ストリーマが収縮・局在化 するためである。また，本報告において，最も細い電極溝 が得られたのは, $p=152 \mathrm{kPa}, l=4 \mathrm{~mm}, V_{d}=4.4 \mathrm{kV}$ 印加時 に $10 \mathrm{~s}$ のエッチング処理を行った場合であり, 溝幅は $68 \mu \mathrm{m}$ であった。しかし，図 5, 図6, 図 7 のいずれの結果におい ても，等しい放電維持電圧印加時において， $l$ は $2 \mathrm{~mm}$ と短 い方が細い溝幅の電極溝が得られた。この理由として $l$ の変 化に伴い，放電中で生成される $\mathrm{CF}_{3}$ や $\mathrm{F}_{2}$ 等のラジカル活性 種の生成量の変化が考えられる。

図 2 に示した $V_{d}=5.0 \mathrm{kV}$ 印加時における放電電流波形を $100 \mathrm{MHz}$ の高周波帯域デジタルフィルタ処理により，変位 電流成分を除去した電流波形を図 9 に示す。〈3・1〉節で述 ベたように，放電電流波形には，微小な放電ギャップと誘 電体材料の静電容量による変位電流成分に加え, 沿面ス卜

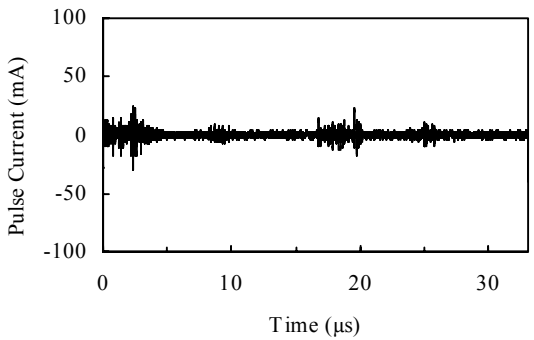

(a) $l=2 \mathrm{~mm}, p=101 \mathrm{kPa}$

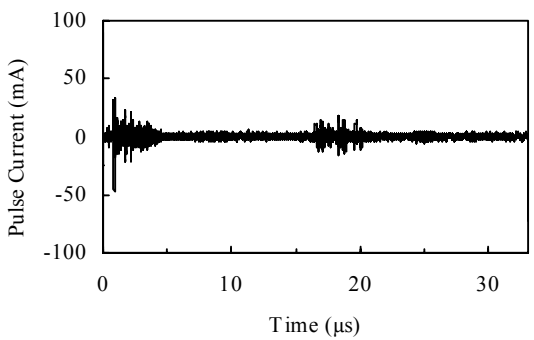

(b) $l=2 \mathrm{~mm}, p=152 \mathrm{kPa}$

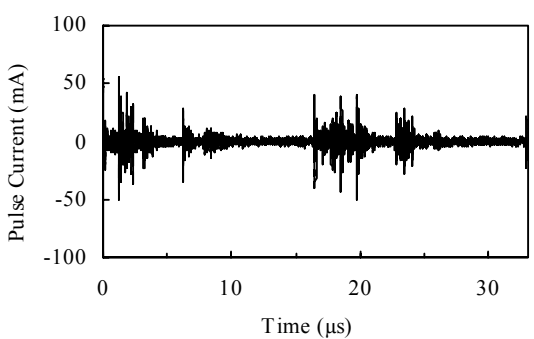

(c) $l=4 \mathrm{~mm}, p=101 \mathrm{kPa}$

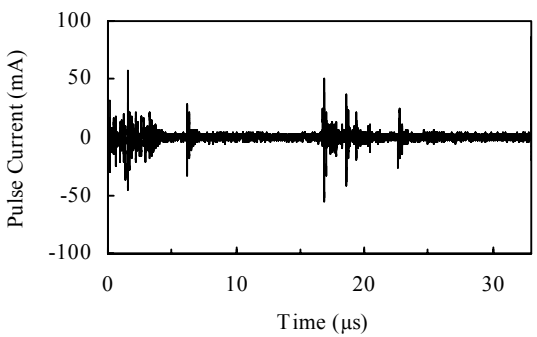

(d) $l=4 \mathrm{~mm}, p=152 \mathrm{kPa}$

図 $9100 \mathrm{MHz}$ 高周波帯域フィルタ処理後の電流波形

Fig. 9. Waveforms of $100 \mathrm{MHz}$ digital-high-pass-filtered discharge current.

リーマ発生時に観測される ns オーダのパルス電流が重畳し ている。従って, 高周波帯域デジタルフィルタ処理により, 変位電流成分を除去し, 沿面ストリーマ生成時に発生する パルス電流のみ取り出した。図 9 より $, l=2 \mathrm{~mm}, 4 \mathrm{~mm}$ を 比較した場合, 背後電極長が長い $l=4 \mathrm{~mm}$ の場合において 大きなパルス電流が観測される。即ち, lが長い場合, 沿面 ストリーマ長が伸展し, パルス電流の值は高くなるため, 電流密度も増加する。これにより, SiN 膜のエッチングに寄 与寸る $\mathrm{CF}_{3}$ や $\mathrm{F}_{2}$ 等のラジカル活性種の生成量が増加するた め, 幅方向へのラジカルエッチングが活発となる。また, 等しい放電維持電圧下において $p$ が上昇した場合, 観測さ れたパルス電流の值は僅かにではあるが小さかった。これ は, $p$ が上昇すると, 放電開始電圧 $\left(V_{s}\right)$ が上昇するためであ る。なお，観測されるパルス電流の大きさは $V_{d}$ に依存する 
ことに加えて，放電管内の気体粒子数が増加することによ り, 電子やイオン, 中性粒子間の衝突が非常に活発となる。 その結果, $p$ が高くなると, パルス電流は小さくなるため, ラジカルの生成量は少なくなるだけでなく, 放電は収縮・ 局在化するため, 細い電極溝の作製が可能となる。

また, 電極溝は $V_{d}$ の上昇, 及び $t_{e}$ の経過に伴い, 幅方向 へ拡がっていくことが明らかとなった。これは， $V_{d}$ が上昇 すると, 放電領域内で生成された SiN のエッチングに重要 な役割を果たす $\mathrm{CF}_{3}$ や $\mathrm{F}$ 等の活性種の生成も活発となり, 幅方向へのラジカルエッチングが進行するためである。ま た, $t_{e}$ の経過に伴い, 活性種による幅方向へのエッチングが 進行するためである。しかしながら, 図6, 図 7 の結果より, $p=152 \mathrm{kPa}$ 時においては, $V_{d}$ がある程度上昇, 或いは $t_{e}$ が 一定時間経過することで, 電極溝幅は拡がってゆき, 約 200 $\mu \mathrm{m}$ 程度で飽和する傾向にある。この理由として, 電極溝の 作製の役割を担う沿面ストリーマの直径は約 $200 \mu \mathrm{m}$ である ことから，ストリーマより離れた領域では，放電領域で生 成された活性種の拡散により, エッチングは進行するため, 電極溝幅の拡がりは約 $200 \mu \mathrm{m}$ 付近から飽和していく傾向に ある。

以上のことから, より細い電極溝を作製するためには, 比較的高圧力下にて沿面放電プラズマ領域を局在化させた うえで, 高い $V_{d}$ を印加し, 短時間でエッチングを行うこと が有効であり, さらに, 背後電極長 $(l)$ を短く設定することが 有効であることが明らかとなった。なお，本研究において 膜厚 $150 \mathrm{~nm}$ の $\mathrm{SiN}$ 膜をエッチングした電極溝は最短で $3 \mathrm{~s}$ のエッチング時間で得られることが明らかとなった。

ところで, SIM 観察により電極溝領域の中心領域では $\mathrm{SiN}$ 膜は完全にエッチングされていたが，エッジ領域ではテク スチャ構造の底部において, $\mathrm{SiN}$ 残膜が確認された。これは, 太陽電池用シリコン基板表面に作製されたピラミッド状テ クスチャ上に LP-CVD により SiN 膜を蒸着するため, テク スチャの頂上よりも底部において, 膜厚が厚くなり易いこ とが挙げられる ${ }^{(9)}$ 。さらに, 沿面放電は誘電体側面に沿って 生成されるため, プラズマ領域から離れるにつれて, エッ チングに寄与するラジカルの供給が十分でなく, エッチン グの進行はエッジに向からにつれて遅い。また，ガラス誘 電体に覆われていた側のエッジでは，ガラス誘電体の角の 曲率により生じる僅かな微小空間で発生する誘電体バリア 放電によりエッチングが行われるが，ガス粒子の供給が外 側の領域に比べ不十分であるため, 微小空隙により形成さ れる電極溝のエッジ領域におけるエッチングの進行は電極 溝中心領域に比べて遅い。従って, 電極溝の作製にあたり, ガラス誘電体角の曲率は直角に近い程, 不十分なエッジ領 域を小さくすることが可能となる。また，エッチングにお いても，テクスチャ頂上は，電界が集中するため, 沿面放 電内部で生成されるイオンから受けるエネルギーがテクス チャ底部に比べて大きい。深さ方向のエッチングに関して は, 文献(5)より，180s 経過してもシリコンテクスチャ構造 に変化はほとんどみられない。また，本研究では短時間か
つ細い幅の電極溝の作製を目的としており, SiN 膜のみエッ チング可能な最短時間のエッチング処理を行っており, SiN 膜下地のシリコン層への影響はほとんどない。

さらに，本研究で取り扱う沿面放電は大気圧ないし，大 気圧以上の高気圧下で非熱平衡プラズマを生成可能な放電 生成システムであり, 半導体製造工程として一般的に用い られている低気圧プラズマシステムに比べ, 粒子間の衝突 距離の平均である平均自由行程が非常に短く, 基板表面一 到達するエネルギーは非常に小さい。そのため, 半導体基 板表面へのダメージも低気圧プラズマに比べて非常に小さ く, 高エネルギーのレーザアブレーションによる手法やダ イシング装置による機械的なエッチングと比較してもラジ カルやイオンによるイオンアシストエッチングである本手 法は低ダメージな手法であると言える。加えて, 沿面放電 の生成に最も重要な役割を果たすガラス誘電体は, 実験上 の取り扱いに注意を要するが, 沿面放電自体による誘電体 ガラスへのダメージは小さい。

最後に, 沿面放電による電極溝のエッチング形状につい ては, 文献( 7 )において $\operatorname{SiN}$ 膜のエッチング残膜の厚みを計 測することで，エッチング断面のプロファイルに関する報 告をしたが, 本研究で取り扱う太陽電池用単結晶シリコン 基板では表面粗さ約 $10 \mu \mathrm{m}$ 程度のランダムなサイズのピラ ミッド状テクスチャ構造上に形成された膜厚約 $150 \mathrm{~nm}$ の $\mathrm{SiN}$ 膜のエッチングを $10 \mathrm{~s}$ 以内の短時間で行っており, 深さ 数 $\mu \mathrm{m}$ に及ぶようなエッチングは行っていない。従って, 本 提案の沿面放電プラズマ源における正確な深さ方向のエッ チング特性を論じる際には, 平滑シリコン基板を用いてエ ッチング処理を行って評価する必要がある。なお, 本研究 では, テクスチャ処理の施された太陽電池用単結晶シリコ ン基板上に形成された SiN 膜をエッチングした電極溝を作 製することを目的としているので，プラズマ源の深さ方向 のエッチング特性を明らかにするための研究は別途行って いるところである。

\section{5. まとめ}

本研究により, 大気圧以上の高気圧沿面放電プラズマに よるエッチングは, 太陽電池用単結晶シリコン基板表面に おける受光面電極用電極溝の作製に有効であり, 背後電極 長が沿面ストリーマの伸展に影響を及ぼし, 幅方向への SiN 膜のエッチングに重要な役割を担っていることが明らかと なった。また, 幅の細い電極溝を作製するためには, 高い 放電維持電圧で短時間のエッチングが有効であった。加え て, 背後電極長を短く設定し, 活性種の拡散を抑制するこ とが幅の細い電極溝の作製に有効であることが明らかとな った。

\section{謝 辞}

本研究の実施にあたり, 宮崎大学の近藤龍治氏, 六田朋 美氏には実験の補助をして頂き感謝します。同様に崇城大 学の松熊邦浩教授, 宮崎大学の本田親久教授, 九州工業大 学の若山登博士, (株エム・セテックの松井和夫氏, 長澤和 
男氏には貴重な助言と指導を賜り深く感謝致します。また, (株エム・セテックには，実験試料や器材の提供をして頂き ました。ここに謝意を表します。

本研究は科学研究費補助金 若手研究(B)(課題番号： 18740355)の補助を受けて行われた。

(平成 20 年 1 月 8 日受付, 平成 20 年 7 月 3 日再受付)

\section{文}

\section{献}

(1) J. Horzel, J. Szlufcik, J. Nijs, and R. Mertens : "A Simple Processing Sequence for Selective Emitters", Proc. of 26th International Photovoltaic Science and Engineering Conference, pp.139-142 (1997)

(2) 電気学会太陽電池調査専門委員会 : 太陽電池ハンドブック, コロナ 社 (1985)

( 3 ) S. R. Wenham, C. B. Honsberg, and M. A. Green : "Buried Contact Silicon Solar Cells", Sol. En. Mat. and Solar Cells, Vol.34, pp.101-110 (1994)

(4) P. Fath: "Processing, Characterization, and Simulation of Mechanically Textured Crystalline Silicon Solar Cells", PhD Thesis, University of Konstantz, ISBN3-930803-75-5 (1998)

(5) 林泉: プラズマ工学, 朝倉書店 (2002)

(6) T. Sakoda, T. Hamada, K. Matsukuma, H. Herai, K. Matsui, and K. Nagasawa : "Selective Etching of Silicon Nitride Film on Single Crystalline Silicon Solar Cell Using Intensive Surface Discharge", Jpn. J. Appl. Phys., Vol.45, No.5A, pp.3992-3993 (2006)

( 7 ) T. Hamada, T. Sakoda, K. Matsukuma, H. Herai, K. Matsui, and K. Nagasawa : "Studies of Conditions Required for Formation of Electrode Grooves on Silicon Solar Cell Using Surface Discharge", Proc. of 13th Asian Conference on Electrical Discharge, No.O-14, p.19 (2006)

(8) T. Hamada, T. Sakoda, M. Otsubo, K. Matsui, and K. Nagasawa : "Evaluation of Electrode Grooves Formed Using Surface Discharge Plasma", Proc. of $18^{\text {th }}$ International Symposium on Plasma Chemistry, No.28P-74, CD-ROM (2006)

(9) T. Hamada, S. Arakawa, T. Sakoda, M. Otsubo, K. Matsui, and K. Nagasawa : "Optimization of Convex Electrode Geometry for Surface Discharge Used for Fabrication of the Electrode Groove on Solar Cells", Surface Coatings \& Technology : (2009) (in press)
濱 田 俊 之 (学生員) 1983 年 3 月 20 日生。 2007 年 3 月崇

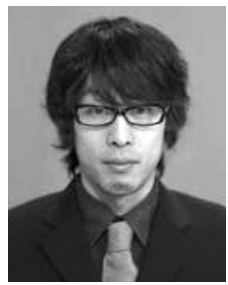
城大学大学院工学研究科修士課程修了。同年 4 月宮崎大学大学院農学工学総合研究科博士後 期課程に入学, 現在に至る。主として, プラズ マ表面処理, レーザ応用プラズマ計測に関する 研究に従事。応用物理学会会員。

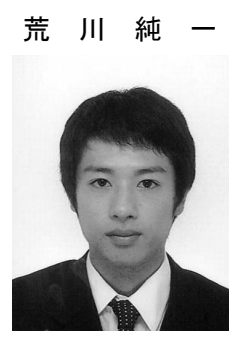

（非会員） 1983 年 10 月 10 日生。 2008 年 3 月 宮崎大学大学院工学研究科修士課程修了。同年 4 月富士電機システムズ (株) に入社, 現在に 至る。

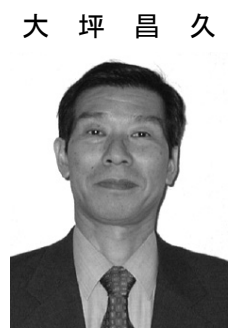

（正員） 1947 年 1 月 10 日生。1970 年 3 月宮崎 大学工学専攻科電気工学専攻修了。同年 4 月宮 崎大学工学部助手, 現在同電気電子工学科教 授。工学博士。放電と応用，電力工学に関する 研究に従事。2002 年第 50 回電気科学技術奨励 賞 (オーム技術賞) 受賞。応用物理学会, 静電 気学会, IEEE 会員。

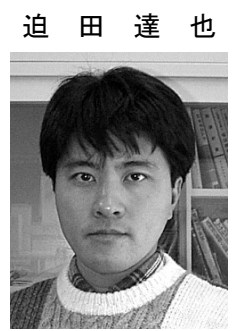

（正員） 1970 年 8 月 10 日生。1998 年 3 月九州 大学大学院総合理工学研究科博士後期課程修 了。同年 4 月熊本工業大学 (現 崇城大学) に 助手として採用され，2000 年 4 月同講師, 2005 年 4 月同助教授を経て, 2006 年 11 月より宮崎 大学准教授, 現在に至る。高電圧プラズマ工学, レーザ応用プラズマ計測の研究に従事。博士 (工学)。応用物理学会, 放電学会会員。 